\title{
Two episodes of Mesozoic mafic dyke swarms from the eastern part of central Inner Mongolia: Petrogenesis and tectonic implications
}

\author{
ZHILI YANG ${ }^{1}$ AND XIAOHUI ZHANG ${ }^{1,2 *}$ \\ ${ }^{1}$ State Key Laboratory of Lithospheric Evolution, Institute of \\ Geology and Geophysics, Chinese Academy of Sciences, \\ Beijing 100029, China \\ ${ }^{2}$ Innovation Academy for Earth Science, Chinese Academy \\ of Sciences, Beijing 100029, China (*correspondence: \\ zhangxh@mail.iggcas.ac.cn)
}

Mafic dyke swarms at the convergent plate margins hold a key to monitoring important geodynamic processes and deep crust-mantle interactions within an extensional accretionary orogen. This zircon U-Pb dating and geochemical study documents two episodes of Mesozoic mafic intrusions from eastern Central Asian Orogenic Belt: the Dong Ujimqin suite (DUS) with an age of ca. $181 \mathrm{Ma}$ and the Xi Ujimqin suite (XUS) with an age of ca. $131 \mathrm{Ma}$. The DUS meta-gabbros are tholeiitic, obvious enrichment in LREEs and depletion in HFSEs, and possesses variable whole-rock initial ${ }^{87} \mathrm{Sr} /{ }^{86} \mathrm{Sr}$ ratios $(0.704608$ to 0.706048$)$, positive $\varepsilon_{\mathrm{Nd}(\mathrm{t})}(+1.15$ to +2.35$)$ and zircon $\delta^{18} \mathrm{O}(5.36$ to $6.46 \%$ ) values. These features endow the DUS with a juvenile subduction fluid-metasomatized lithospheric mantle source. By contrast, the XUS exhibits a meta-monzodiorite composition and a transitional character from calc-alkaline to tholeiitic, enriched in LREEs and LILEs, depleted in HFSEs, with whole-rock $\mathrm{Sr}-\mathrm{Nd}$ (initial ${ }^{87} \mathrm{Sr} /{ }^{86} \mathrm{Sr}=0.705656$ to $0.705695, \varepsilon \mathrm{Nd}(\mathrm{t})=-0.91$ to -1.11$)$ and zircon $\mathrm{O}\left(\delta^{18} \mathrm{O}=5.40\right.$ to $9.62 \%$ ) isotopic values. These elements and isotopic traits suggest a derivation from low-degree melting of amphibolebearing lherzolites in the lithospheric mantle that had been metasomatized by subducting slab-derived fluids. Besides representing the first recognition of distinct Mesozoic mantle melting events in the region, the present two mafic magmatic suites witnessed a shift from a subduction-related continental back-arc environment to a post-orogenic extensional regime in the Mongol-Okhotsk tectonic domain. Considering their respective temporal coincidence with the subduction of the Mongol-Okhotsk ocean and the initial rifting in the regional basins, these two episodes of Mesozoic mafic intrusions could not only serve as spatial markers for relating magmatic underplating with basin formation, but also capture a unique trace of extension-induced deep crust-mantle interactions in response to lithospheric dripping and gravitational collapse under a post-orogenic extensional regime. This study was supported by the NNSFC (41873035). 